\title{
Maternal and perinatal outcome in placenta previa - one year study in tertiary care center in Tamil Nadu, India
}

\author{
Raja Rajeshwari R.*, Rubini M.
}

Department of Obstetrics and Gynaecology, Thanjavur Medical College Hospital, Thanjavur, Tamil Nadu, India

Received: 24 June 2016

Accepted: 12 July 2016

\section{*Correspondence:}

Dr. Raja Rajeshwari R.,

E-mail: drrrrpanju@gmail.com

Copyright: $\odot$ the author(s), publisher and licensee Medip Academy. This is an open-access article distributed under the terms of the Creative Commons Attribution Non-Commercial License, which permits unrestricted non-commercial use, distribution, and reproduction in any medium, provided the original work is properly cited.

\section{ABSTRACT}

Background: Obstetric hemorrhage is one of the most dangerous and devasting group of disorders in Obstetrics of which placenta previa contributes $1 / 5^{\text {th }}$ of the cases. The aim of this study was to analyze the obstetrical factors and the maternal and perinatal outcome of these cases.

Methods: This was a retrospective study conducted in the Department of Obstetrics and Gynecology of Thanjavur Medical College Hospital, Thanjavur from August 2014 - July 2015. Chart records of all women who had undergone cesarean section for placenta previa were reviewed. Relevant clinical findings were noted.

Results: In the present study, 134 cases of placenta previa were studied regarding type of clinical presentation, clinical course, maternal and perinatal outcome. Information obtained was arranged statistically. A placenta previa case was highest in the age group 20-29 years (79.85\%) and in multiparous group (63.43\%). Most common risk factor was previous cesarean section (39.5\%) followed by abortion in $24.6 \%$. Major degree of placenta previa constitutes $69.4 \%$ i.e., majority of cases and minor degree constitutes $30.59 \%$ of cases. In the present study massive blood transfusion was required in $0.04 \%$ of all cases, adherent placenta previa in $1.9 \%, 12.68 \%$ required hysterectomy. Perinatal morbidity was $25.92 \%$ and perinatal mortality incidence was $16.41 \%$. Prematurity contributed the most $63.6 \%$ followed by RDS about $4.58 \%$. Newborn with weight above $2 \mathrm{~kg}$ has very good survival rates, whereas newborn with weight $<1 \mathrm{~kg}$ has poor survival rates.

Conclusions: Placenta previa poses danger to both the mother and the baby with high maternal morbidity and adverse perinatal outcome.

Keywords: Maternal and perinatal outcome, Placenta previa, Risk factors

\section{INTRODUCTION}

Obstetric hemorrhage is one of the most common causes of maternal morbidity and mortality worldwide. Abnormal placentation is currently the most common indication for peripartum hysterectomy. Placenta previa accounts for one third of all cases of APH. ${ }^{1}$ Placenta previa is a major risk factor for obstetric haemorrhage especially in women with a previous uterine scar. ${ }^{2}$ Placenta previa defined as implantation of placenta in lower uterine segment, overlying or approaching internal cervical os. ${ }^{3}$ It is further classified according to William's as: ${ }^{4}$
A. Total placental previa: Internal cervical os is covered completely by the placenta.

B. Partial placenta previa: Internal os is partially covered by the placenta.

C. Marginal placenta previa: Edge of the placenta is at the margin of the internal os.

D. Low lying placenta: Placenta is implanted in the lower uterine segment such that the placental edge does not reach the internal os but in close proximity to it.

It occurs in 2.8/1000 and 3.9/1000 in singleton and twin pregnancies respectively. ${ }^{5}$ Risk factors include high parity, advancing maternal age, previous cesaerean 
section and uterine surgery. ${ }^{6}$ The main diagnostic modality is by transvaginal ultrasound. Every women with suspected diagnosis of placenta previa at anomaly scan needs further follow up imaging. ${ }^{22}$ Early prenatal diagnosis allows for timely management thus reducing the perinatal and maternal morbidity and mortality by keeping an eye on need of blood transfusion, and arranging for a team of experienced surgeon, anaesthesiologist and paediatrician. The risk of placenta previa in post cesaerean pregnancy has been reported to be higher than after vaginal delivery. ${ }^{7}$ As there is an increase in primary cesarean rate, and increased incidence of placenta previa the purpose of this study is to assess the value of demographic profile and early identification of placenta previa in the maternal and perinatal outcome.

\section{METHODS}

This was a retrospective study conducted in the Department of Obstetrics and Gynecology of Thanjavur Medical College Hospital, Thanjavur from August 2014 July 2015. Chart records of all women who had undergone cesarean section for placenta previa were reviewed. Relevant clinical findings were noted.

\section{RESULTS}

Table 1: Demographic profile.

\begin{tabular}{|llll|}
\hline Parameters & & $\begin{array}{l}\text { No. of } \\
\text { women }\end{array}$ & Percentage \\
\hline Booking & Booked & 21 & $15.7 \%$ \\
\hline \multirow{3}{*}{ status } & Unbooked & 113 & $84.3 \%$ \\
\hline \multirow{2}{*}{ Age } & $20-29$ & 107 & $79.9 \%$ \\
\hline \multirow{2}{*}{ Parity } & $30-35$ & 24 & $17.9 \%$ \\
\cline { 2 - 4 } & $>35$ & 3 & $2.2 \%$ \\
\hline
\end{tabular}

There was total of 14,712 deliveries during that period of August 2014 to July 2015. 134 cases of placenta previa were registered amounting to the incidence of $0.9 \%$. maximum number are unbooked cases with early referral of $2.9 \%$ and delayed referral of $81.3 \%$.Placenta previa cases was highest in the age group 20-29 years i.e. $79.85 \%, 17.91 \%$ in the age group $30-35$ years and $2.23 \%$ in the age group $>35$ years and in the multiparous group $63.43 \%$. Risk factors studied were previous cesarean section, abortion, twin gestation and myomectomy. Most common risk factor was previous cesarean section i.e. $39.5 \%$ followed in order by abortion $24.6 \%$, twin gestation $0.7 \%$. Of the complications studied, severe anaemia contributes to $15.6 \%$, malpresentations to $6.7 \%$, (breech $2.98 \%$, transverse lie $3.71 \%$ ).

I Trimester bleeding contribute to $29.8 \%$, II Trimester bleeding to $32.08 \%$. PIH noted in $2.98 \%$. Incidence of GDM was $1.49 \%$ and IUGR and oligoamnios was $4.47 \%$. Major degree of placenta previa constitutes $69.4 \%$ i.e., majority of cases and minor degree constitutes $30.59 \%$ of cases. In the present study massive blood transfusion was required in $0.04 \%$ of all cases, shock/hypotension observed in $3.7 \%$ of all cases, PPH noticed in $27.6 \%$ of cases, adherent placenta previa in $1.9 \%, 12.68 \%$ required hysterectomy, $2.23 \%$ developed AKI and $4.47 \%$ required ventilatory support.

Table 2: Obstetric evaluation.

\begin{tabular}{|llll|}
\hline \multirow{2}{*}{ Parameters } & & \multicolumn{1}{c|}{$\begin{array}{l}\text { No. of } \\
\text { women }\end{array}$} & Percentage \\
\hline \multirow{2}{*}{ Pain abdomen } & Present & 2 & $1.5 \%$ \\
\cline { 2 - 4 } & Absent & 132 & $98.5 \%$ \\
\hline Presentation & Vertex & 126 & $94 \%$ \\
\cline { 2 - 4 } & Breech & 4 & $3 \%$ \\
\cline { 2 - 4 } & $\begin{array}{l}\text { Transverse } \\
\text { lie }\end{array}$ & 4 & $3 \%$ \\
\hline $\begin{array}{l}\text { Previous } \\
\text { obstetric } \\
\text { performance }\end{array}$ & LSCS & 53 & $40 \%$ \\
\cline { 2 - 4 } & Abortion & 33 & $25 \%$ \\
\hline
\end{tabular}

Table 3: Types of placenta previa.

\begin{tabular}{|lll|}
\hline Type of placenta & No. of women & Percentage \\
\hline I & 21 & $16 \%$ \\
\hline Ii & 50 & $37 \%$ \\
\hline Iii & 39 & $29 \%$ \\
\hline Iv & 24 & $18 \%$ \\
\hline
\end{tabular}

Table 4: Antenatal, intraoperative and post-operative complications.

\begin{tabular}{|lll|}
\hline Antenatal & $\begin{array}{c}\text { No. of } \\
\text { women }\end{array}$ & Percentage \\
\hline Severe anemia & 21 & $15.6 \%$ \\
\hline Coexisting PIH & 4 & $3 \%$ \\
\hline IUD & 4 & $3 \%$ \\
\hline GDM & 2 & $1.5 \%$ \\
\hline IUGR/OLIGO & 6 & $4.5 \%$ \\
\hline Intraoperative and post-operative & \\
\hline Shock/hypotension & 5 & $3.7 \%$ \\
\hline Sepsis & 1 & $0.007 \%$ \\
\hline Febrile morbidity & 0 & 0 \\
\hline PPH & 37 & $27.6 \%$ \\
\hline Adherent placenta & 2 & $1.9 \%$ \\
\hline AKI & 3 & $2.2 \%$ \\
\hline
\end{tabular}

Perinatal morbidity studied as percentage of babies requiring resuscitaton and NICU admission was 25.92\%.Perinatal mortality incidence was $16.41 \%$. Prematurity contributed the most $63.6 \%$ followed by RDS about $4.58 \%$. Perinatal deaths in types of placenta previa. Minor $-17.07 \%$, Major-20.43\%.Perinatal deaths were observed only in cases of abdominal delivery about $19.54 \%$. Perinatal mortality was more in the age group 28-33 weeks of gestation is $88.8 \%$, whereas in $34-36$ 
weeks of gestation it was $17.7 \%$ and it is almost nil in $>37$ weeks of gestation. Newborn with weight above $2 \mathrm{~kg}$ has very good survival rates, whereas newborn with weight $<1 \mathrm{~kg}$ has poor survival rates.

Table 5: Neonatal outcome.

\begin{tabular}{|ll|l|}
\hline Parameters & No. of women & Percentage \\
\hline NICU admission & 32 & $23.7 \%$ \\
\hline $\begin{array}{l}\text { Neonatal mortality } \\
\text { causes - asphyxia }\end{array}$ & 2 & $1.5 \%$ \\
\hline Prematurity & 14 & $63.6 \%$ \\
\hline IVH & 0 & 0 \\
\hline RDS & 6 & $5 \%$ \\
\hline
\end{tabular}

\section{DISCUSSION}

There were 134 cases presented with placenta previa and incidence amounting to $0.9 \%$. Mean age of presentation is 29years. APH complicates $2-5 \%$ of pregnancies of which approximately one third are due to placenta previa. ${ }^{7}$ Various studies have shown the incidence of placenta previa ranging from 0.33 to $0.38 \%$ of deliveries. $^{8,9}$

Increasing age and number of pregnancies have been shown to be an important risk factor for placenta previa. This study had one third of the patient above 30 years age group and almost two third (75\%) of the women were multipara. According to Cleary et al, a prospective database from multicenter investigations of 36,056 women with singletons showed increasing age was significantly associated with placenta previa comparing women less than 35 years to $35-29$ years and 40 years and older (OR 1.8 and 2.8 respectively).Multiple studies have shown increasing parity to be an important risk factor for placenta previa. ${ }^{10-12}$

Table 6: Comparison of various studies of placenta previa - distribution.

\begin{tabular}{|lll|}
\hline Authors & Year & $\begin{array}{l}\text { Placenta previa - } \\
\text { distribution }\end{array}$ \\
\hline Bhatt & 1971 & $36.8 \%$ \\
\hline Daftary et al & 1981 & $40 \%$ \\
\hline Arora et al $^{18}$ & 2001 & $46.4 \%$ \\
\hline $\begin{array}{l}\text { Chauhan and } \\
\text { Krishna }\end{array}$ & 2001 & $33.3 \%$ \\
\hline
\end{tabular}

Regarding previous obstetric history, $40 \%$ had previous LSCS while $20 \%$ had history of abortion. In a retrospective cohort study of 399,674 women, the rate for placenta previa at second birth for women with first vaginal birth was 4.4 per 1000 births, compared to 8.7 per 1000 birth for women with cesarean section at first birth. After adjustment cesarean section at first birth remained associated with increased risk of placenta previa (OR 1.6 95\% CI 1.44-1.76).Previous history of abortions (both spontaneous and induced) have been significantly associated with up to three times risk of placenta previa. ${ }^{8,14-16}$

Regarding mode of delivery, cesarean section has been the recommended mode of delivery for major placenta previa. Vergani and colleagues reported that more than two thirds of women with placental edge and os distance $>1 \mathrm{~cm}$ and $1-2 \mathrm{~cm}$ within 4 weeks of delivery according to Bronsteen had successful vaginal delivery. ${ }^{19,20}$ In our case, only one had normal successful vaginal delivery.

Women who had previous cesarean section with either placenta previa or anterior placenta underlying scar are at increased risk of placenta accreta. ${ }^{21}$ Colour flow Doppler is useful diagnostic modality. MRI is recommended, if ultrasound is inconclusive.

In population based retrospective cohort study in Nova Scotia, Canada from 1988-1995, 308 cases of placenta previa were identified. Maternal complications included postpartum bleeding (RR-1.86), hysterectomy (RR 33.26), blood transfusion (RR-10.05), and septicemia (RR-5.55). Risk factor for hysterectomy in women with placenta previa included presence of placenta accrete and previous cesarean. ${ }^{9}$ This is similar to the case of cesarean hysterectomy this study who had history of previous cesarean section and there was morbid placental adhesion. Sheiner et al found pregnancies complicated by placenta previa had significantly higher rate of postpartum hemorrhage (OR: 3.8, 95\%CI: 1.2-10.5), malpresentations (OR: 7.6, 95\% CI: 5.7-10.1), abruption placenta (OR: 13.1, 95\% CI: 8.2-20.7).

A population based retrospective cohort study among singleton 544,734 mother-infant pair showed that the association between low birth weight and placenta previa is chiefly due to preterm delivery and to lesser extent to fetal growth restriction. ${ }^{14}$ Sheiner showed that congenital malformations and perinatal mortality was 2.6 times more common among cases with placenta previa as compare to those without it. In this study $64 \%$ of babies had low birth weight and $10 \%$ of the babies had neonatal death. Increased perinatal mortality as well as neonatal death has been noted in other studies. ${ }^{17}$

\section{CONCLUSION}

Placenta previa accounts for approximately $0.9 \%$ of all deliveries. Majority of the patients were from rural areas where they were unaware about the importance of antenatal visits, with poor educational standards and were of low socioeconomic status. Increasing use of primary cesarean section results in increasing incidence of placenta previa as well as accreta. As the maternal and perinatal morbidity and mortality due to placenta previa is preventable, efforts should be made to bring down these rates which can be achieved by spacing pregnancies, limitation of family size, antenatal registration of all pregnant patients, use of routine USG in pregnancy and early referral of high risk pregnant 
women to tertiary care centers. Awareness should be brought about in the rural public to avail the facilities provided by the Government. This will definitely help in better outcome of both mother and fetus in all high risk pregnancies.

Funding: No funding sources

Conflict of interest: None declared

Ethical approval: The study was approved by the Institutional Ethics Committee

\section{REFERENCES}

1. Dutta DC; Antepartum haemorrhage. Konar HL editor; Text book of obstetrics. 8th edition. New Central Book Agency, Kolkata. 2015:282-284.

2. Getahun D, Oyelesse Y, Salihu HM,Ananth CV. Previous Caesarean Delivery and Risks Of Placenta Previa And Abruption. Obstet Gynecol. 2006; 107:771-8.

3. Elsayes KM, Trout AT, Friedkin AM, Liu PS, Bude RO, Platt JF, et al. Imaging of the placenta: a multimodality pictorial review. Radiographics, 2009;29(5):1371-91.

4. Williams Text Book of Obstetrics. $24^{\text {th }}$ Edition, Obstetrical Hemorrhage. 2014:800.

5. Oppenheimer L. Society of obstetricians and gynecologists of Canada; Diagnosis and management of placenta previa. J Obstet Gynecol Can. 2007;29(3):261-6.

6. Sinha P, Kuruba N. Anteparum haemorrhage: an update. J Obstet Gynecol. 2008;28:377-81.

7. Hasegawa J, Matsuoka R, Ichizuaka K, Mimura T, Sekizawa A, Farina A, et al. Predisposing factors for massive haemorrhage during cesarean section in patients with placenta previa. Ultrasound Obstet Gynecol. 2009;34(1):80-4.

8. Sheiner E, Shoham-Vardi I, Hallak M, Hershkowitz R, Katz M, Mazor M. Placenta Previa: obstetric risk factors and pregnancy outcome. The Journal of Maternal-Fetal and Neonatal Medicine. 2001;10(6):414-19.

9. Crane JM, Van den Hof MC, Dodds L, ArmsonBA, Liston R. Maternal complications with placenta previa. Am J Perinatol. 2000;17(2):101-5.

10. Cleary-Goldman J, Malone FD, Vidaver J, Ball RH, Nyberg DA, Comstock CH, et al. Impact of Maternal Age on Obstetric Outcome. Obstet Gynecol. 2005;105(5 Pt 1):983-90.
11. Babinszki A, Kerenyi T, Torok O, et al. Perinatal outcome in grand and great-grand multiparity: Effects of parity on obstetric risk factors. Am J Obstet Gynecol. 1999;181:669.

12. Gilliam M, Rosenberg D, Davis F. The likelihood of placenta previa with greater number of cesarean delivery and higher parity. Obstet Gynecol. 2002;99(6):976-80.

13. To WW, Leung WC. Placenta previa and previous cesarean section. Int $\mathrm{J}$ Gynaecol Obstet. 1995;51(1):25-31.

14. Ananth CV, Smulian JC, Vintzileos AM. The association of placneta previa with history of cesarean delivery and abortion: A metaanalysis. AJOG. 1997;177(5):1071-8.

15. Johnson LG, Mueller BA, Daling JR. The relationship of placenta previa and history of induced abortion. Int J Gynecol Obstet. 2003;81(2):191-8.

16. Hung TH, Hsieh CC, Hsu JJ, Chiu TH, Lo LM, Hsieh TT. Risk factors for placenta previa in an Asian population. Int $\mathbf{J}$ Gynecol Obstet. 2007;97(1):26-30.

17. Ananth CV, Smulian JC, Vintzileos AM. The effect of placenta previa on neonatal mortality: a population based study in United States 1989 through 1997. Am J Obstet Gynecol. 2003;188:1299304.

18. Arora R, Devi U, Majumdar K. Perinatal Morbidity and Mortality In Antepartum Hemorrhage. J Obstet Gynaecol India. 2001;51(3):102.

19. Vergani P, Ornaghi S, Pozzi I. Placenta previa: distance to internal os and mode of delivery. Am J Obstet Gynecol. 2009;201(3):266.e1-5

20. Bronsteen R, Valice R, Lee W, Blackwell S. Effect of a low-lying placenta on delivery outcome. Ultrasound Obstet Gynecol. 2009;33(2):204.

21. Antepartum Hemorrhage. Clinical Green Top Guideline No 63. The Royal College of Obstetrician And Gynecologist, Nov 2011.

22. Placenta Previa, Accrete and Vasa Previa: Diagnosis And Management .Green Top Guidelines No 27. Royal College of Obstetricians and Gynaecologists revised Jan 2011.

Cite this article as: Rajeshwari RR, Rubini M. Maternal and perinatal outcome in placenta previa one year study in tertiary care center in Tamil Nadu, India. Int J Reprod Contracept Obstet Gynecol 2016;5:2819-22. 